ISSN 1112-9867

http://www.jfas.info

\title{
THE ASSESSMENT OF AMBIENT AIR POLLUTION PATTERN IN SHAH ALAM, SELANGOR, MALAYSIA
}

U. A. Zakaria ${ }^{1}$, A. S. M. Saudi ${ }^{1, *}$, I. F. Abu ${ }^{1}$, A. Azid ${ }^{2}$, A. Balakrishnan ${ }^{1}$, N. A. Amin ${ }^{1}$ and Z. I. Rizman ${ }^{3}$

${ }^{1}$ Department of Environmental Healthcare, Institute of Medical Science Technology, Universiti Kuala Lumpur, 43600 Kajang, Selangor, Malaysia

${ }^{2}$ Faculty of Bioresources and Food Industry, Universiti Sultan Zainal Abidin, 22200 Besut, Terengganu, Malaysia

${ }^{3}$ Faculty of Electrical Engineering, Universiti Teknologi MARA, 23000 Dungun, Terengganu, Malaysia

Published online: 05 October 2017

\begin{abstract}
This study implements the statistical analysis to establish the association between air pollution trends with the industrial activities in Shah Alam, Selangor. PCA used to identify most significant parameters contributing to air pollution and it sources of pollutions, whereas SPC used to determine the pattern and contribution each of most significant pollutants in the study area and Spearman Correlation used to determine the relationship between air pollutants and meteorological factors. The result identified the major possible sources of air pollution were $38.3 \%$ and $32.46 \%$ of total variance. The patterns for most significant parameters mostly exceeding RMAAQG from 2009 to 2011 and has improved starting 2012. It also found correlation between air pollutants and meteorological was significantly low.
\end{abstract}

Author Correspondence, e-mail: ahmadshakir@unikl.edu.my

doi: $\underline{\text { http://dx.doi.org/10.4314/jfas.v9i4s.43 }}$ 
Thus, it concluded that pollution in Shah Alam was due to high combustion and emission from vehicles.

Keywords: principal component analysis; statistical process control; spearman correlation; air pollution trends.

\section{INTRODUCTION}

The air quality in Malaysia had reduce gradually due to population growth, industrial activities and urbanization [1]. It might contains a lots of pollutants with non-point sources and this sources can be from the emission of motor vehicles, industrial factories and not to forget tobacco smoke [2]. By controlling the source of pollutant emission, sustainable development can continue and the risk of health effect can be reduced. Therefore, in Malaysia, Department of Environment had managed to build the automatic monitoring named Continuous Air Quality Monitoring (CAQM) in order to detect any changes in ambient air quality and continuously monitor the air quality. Referring to European Nation (EU), the recommended location to locate the stations are at area with a natural ecosystem, low population density and be a good distance from anthropogenic emission sources [3]. Hence, data collected from a rural background CAQM station allows the acquisition of regional trends in air pollutant concentrations with least enhancement resulting from local emissions [4]. In this study, Shah Alam, Selangor is a highly urbanized city which consists of industrial area, residential area and also surrounded by highway and main roads.

\section{EXPERIMENTAL}

\subsection{Description of Study Area}

Shah Alam has the area size of 290.3 square kilometers which is Selangor's state capital city and consists of 56 sections. Shah Alam is located near Klang, Petaling Jaya, Kuala Lumpur, Putrajaya, Kajang and Bangi. It holds 29,026 unit of industries and 650,000 population [5]. It is one of the busiest cities in Malaysia. Shah Alam is also famous with the city concept of "City in a Garden" and has become an attractive destination for tourism [6]. Shah Alam had underwent very rapid urbanization process each and every year, and one of the factors was due to it is surrounded by developing areas of the Klang-Langat Valley [7]. Besides, Shah 
Alam itself is a capital city. It helps to absorb growth and avoid excessive concentration of population in Federal Territory of Kuala Lumpur [8]. The location for air quality monitoring station of Shah Alam is at Section U2 (Taman TTDI Jaya Primary School, Shah Alam), which is at north area with coordinate $3^{\circ} 6^{\prime} 28^{\prime \prime} \mathrm{N}, 101^{\circ} 33^{\prime} 4^{\prime \prime}$ E that being characterized as urban category. In five kilometers radius from its air quality monitoring station, it is surrounded by residential area, near to major roads, industrial area and also Subang Airport.

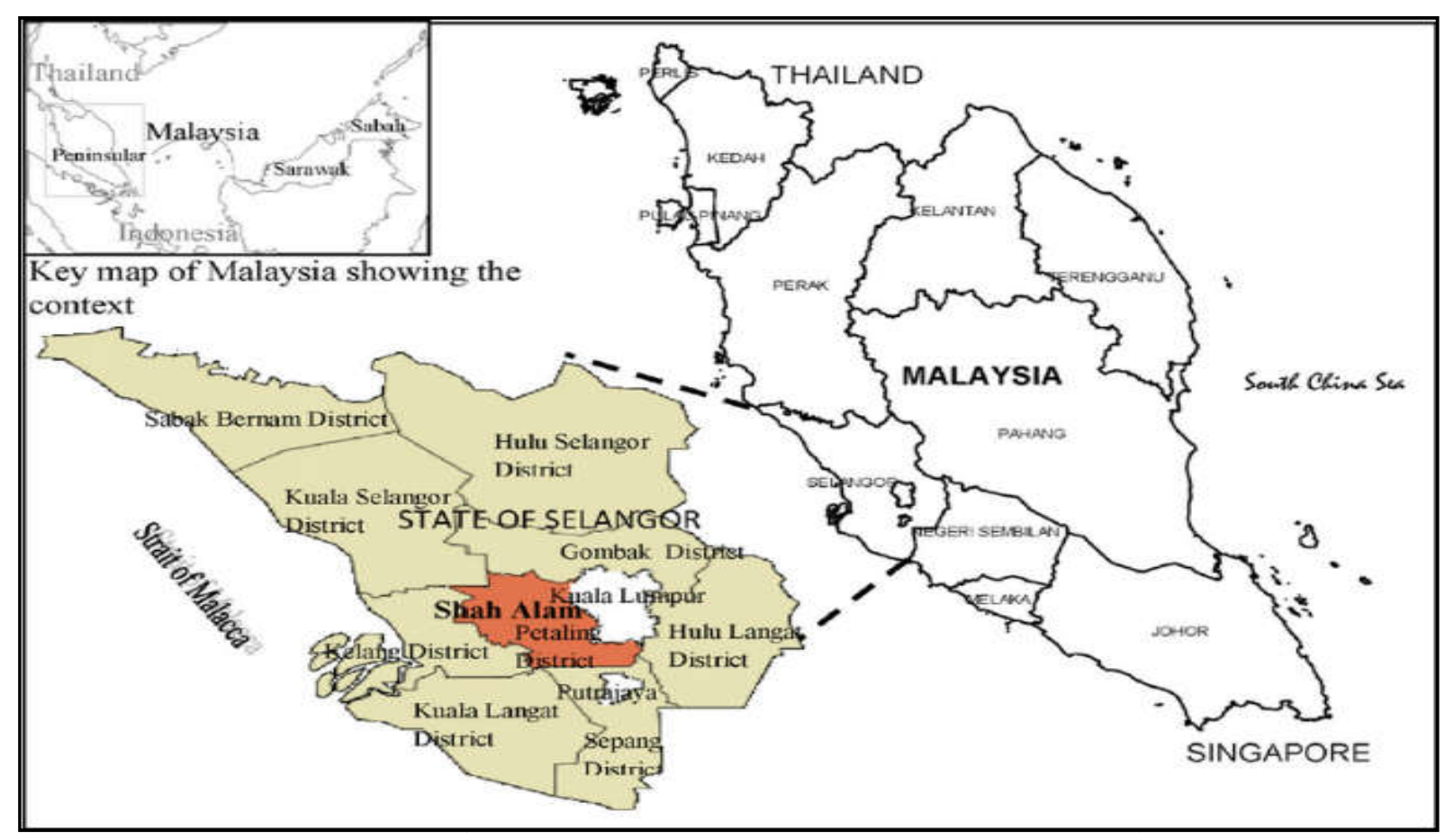

Fig.1. Shah Alam city in map of Selangor

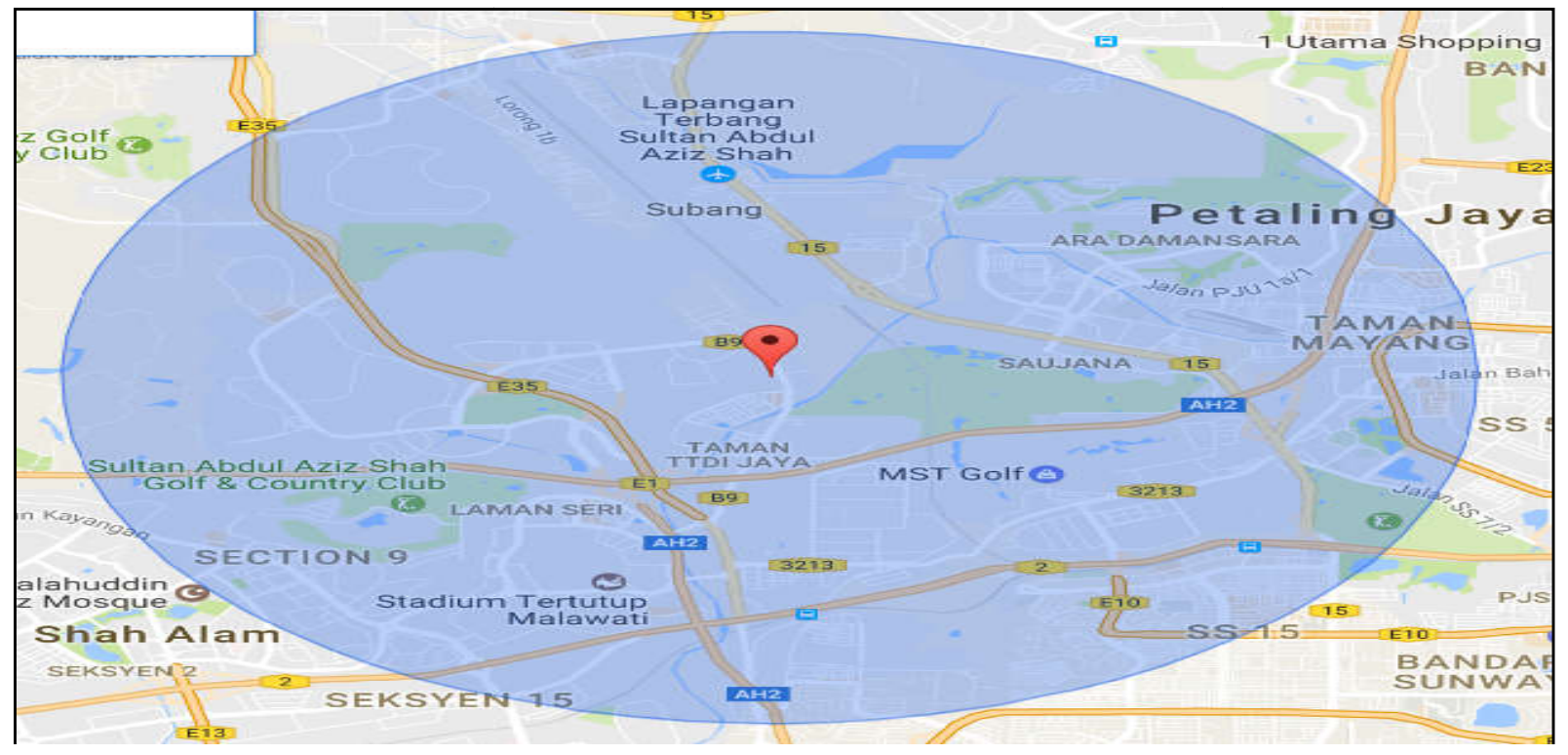

Fig.2 Map with radius within $5 \mathrm{~km}$ from Shah Alam air quality monitoring station 


\subsection{Data Collection}

The data for this study was obtained from Department of Environment (DOE) Malaysia which pollutants reading such as $\mathrm{PM}_{10}, \mathrm{O}_{3}, \mathrm{CO}, \mathrm{SO}_{2}$ and $\mathrm{NO}_{2}$ from 2009 to 2013 used in this study were collected by Alam Sekitar Malaysia (ASMA) Sdn. Bhd.

\subsection{Data Analysis}

\subsubsection{Data Treatment}

The data received from DOE from year 2009 until 2013 were in hourly observation which gave total of 394,416 data sets (43824 x 9) contained some missing value. Therefore, the principle of nearest neighbour method was applied to predict the unknown value by referring to the known value of nearest neighbouring location. The estimation process was conducted using XLSTAT add-in software where the endpoint of the gaps was used to estimates the missing values. The equation used shown as Equation (1) and Equation (2) [9-10]:

$y=y 1$ if $x \leq x 1+[(x 2-x 1) / 2]$

or

$y=y 2$ if $x \geq x 1+[(x 2-x 1) / 2]$

where $y$ represents the interpolate, $x$ is the time point of the interpolate, $y 1$ and $x 1$ are the coordinates of starting point of the gap and $y 2$ and $x 2$ are the end points of the gaps.

\subsubsection{Normality Test}

Jarque-Bera test was used instead of Shapiro-Wilk test in determining the normality of the data. This approach suited for higher number of values compared to Shapiro-Wilk which best for observation that is less than 5000 observations [11], whereby this study comprises almost 400,000 observations. If the computed $p$-value is lower than the significance level alpha (0.05) and the $\mathrm{p}$-value $<0.01, \mathrm{H}_{0}$ should be rejected and alternative hypothesis must be taken. This test can be done when completed dataset without missing value is obtained.

\subsubsection{Identifying Most Significant Parameter and Its Sources of Pollutions}

Principal Component Analysis (PCA) is the frequent technique used to analyze and extract the most significant parameters in a large and complex data set. As a result, it was used to identify the source of emission and to create new variable through original variables [12]. The new variable known as principal component score (PCs). It was calculated by using Equation (3). $z i j=a i 1 \times 1 j+a i 2 x 2 j+a i 3 x 3 j+\ldots \ldots+a i m x m j$ 
(3)

where $z$ is the component score, $a$ is the component loading, $x$ is the measured value of variables, $i$ is the component number, $j$ is the sample number and $m$ is the total number of variables.

\subsubsection{Determination of the Pattern and Contribution of Each Pollutant in the Study} Area

SPC chart is a significant tool in observing and analyzing the data of air pollutant and comparing the result to the needs of the research. From the collected data, the pattern was formed by using the SPC. Referring to the result and graph, we compared the air pollutant pattern with the meteorological pattern to find the significance of their correlation. Besides, it also helps the authority in setting up guidelines and regulations in improving the environmental performance and quality management of a companies and firms [13].

\subsubsection{Correlation of Air Quality Data with Meteorological Data}

The Spearman correlation test was used to determine the relationship between the most significant air pollutant and meteorological factors. In this study, the level of correlation was determined by referring to the correlation coefficient value. The value between 0.0 and 0.25 was considered as low correlation, $0.26-0.50$ as fair correlation, 0.51 to 0.75 as moderate correlation and 0.75-1.00 as high correlation.

\section{RESULTS AND DISCUSSION}

The corrective action towards the missing data found in five years total data set of 394,416 $(43,824 \times 9)$ had completed by using the principle of nearest neighbour method, which had been practice by other previous researchers in their studies such as [14-15]. Hence, the complete data set were obtained and further interpretation had been prepared.

\subsection{Normality Test}

The normality test gave out the result of computed p-value was lower than the significance level alpha (0.05). Therefore, data that extracted in this study did not follow a normal distribution. While, the risk to reject that the data is normal distribution was lower than $0.01 \%$.

\subsection{Identifying the Most Significant Parameters Contributing to the Air Pollution and Its}

\section{Source of Pollution}


In this study, PCA was applied to eight parameters in order to identify the most significant parameter besides to understand the major potential source of pollutants that are contributing to the air pollution in the Shah Alam city. The parameters were wind speed, ambient temperature, humidity, $\mathrm{SO}_{2}, \mathrm{NO}_{2}, \mathrm{O}_{3}, \mathrm{CO}$ and $\mathrm{PM}_{10}$. In this study, only strong factor loadings selected for the PC interpretation [16]. From the analysis, only two PCs were obtained based on eigenvalue more than one (>1), that is F1 (3.064) and F2 (3.597). Their variability accounts for $38.3 \%$ and $32.46 \%$ respectively. The result is shown in Table 1 .

Table 1. Eigenvalues of factors from PCA

\begin{tabular}{ccccccccc}
\hline & F1 & F2 & F3 & F4 & F5 & F6 & F7 & F8 \\
\hline Eigenvalue & 3.064 & 2.597 & 0.70 & 0.55 & 0.41 & 0.37 & 0.25 & 0.06 \\
Variability (\%) & 38.302 & 32.457 & 8.79 & 6.82 & 5.11 & 4.57 & 3.18 & 0.78 \\
Cumulative \% & 38.302 & 70.760 & 79.54 & 86.37 & 91.48 & 96.04 & 99.22 & 100 \\
\hline
\end{tabular}

After numbers of eigenvalues, rotation was applied towards the selected PCs (F) to make the interpretation available. After the rotation applied, VF gained through that rotation [17-18]. The result is presented in Table 2 and Fig. 3, which shown VF1 have strong positive factor loading towards $\mathrm{NO}_{2}(0.875), \mathrm{CO}(0.841)$ and $\mathrm{PM}_{10}(0.834)$. Meanwhile, $\mathrm{SO}_{2}$ and $\mathrm{O}_{3}$ with value 0.618 and 0.713 respectively shown moderate positive factor loading in VF1. On the other hand, second varimax factor (VF2) with eigenvalue 2.597 and variance of $32.457 \%$ showing strong positive factor loading on wind speed (0.823) and ambient temperature (0.941), yet strong negative factor loading on humidity (-0.946). In this study, only strong factor loading will be further discussed.

Table 2. Factor loadings after varimax rotation

\begin{tabular}{ccc}
\hline & VF1 & VF2 \\
\cline { 1 - 3 } Wind speed & -0.042 & $\mathbf{0 . 8 2 3}$ \\
Temperature & 0.004 & $\mathbf{0 . 9 4 1}$ \\
Humidity & 0.010 & $\mathbf{- 0 . 9 4 6}$ \\
$\mathrm{SO}_{2}$ & $\mathbf{0 . 6 1 8}$ & 0.083 \\
$\mathrm{NO}_{2}$ & $\mathbf{0 . 8 7 5}$ & -0.086 \\
$\mathrm{O}_{3}$ & $\mathbf{0 . 7 1 3}$ & 0.319
\end{tabular}




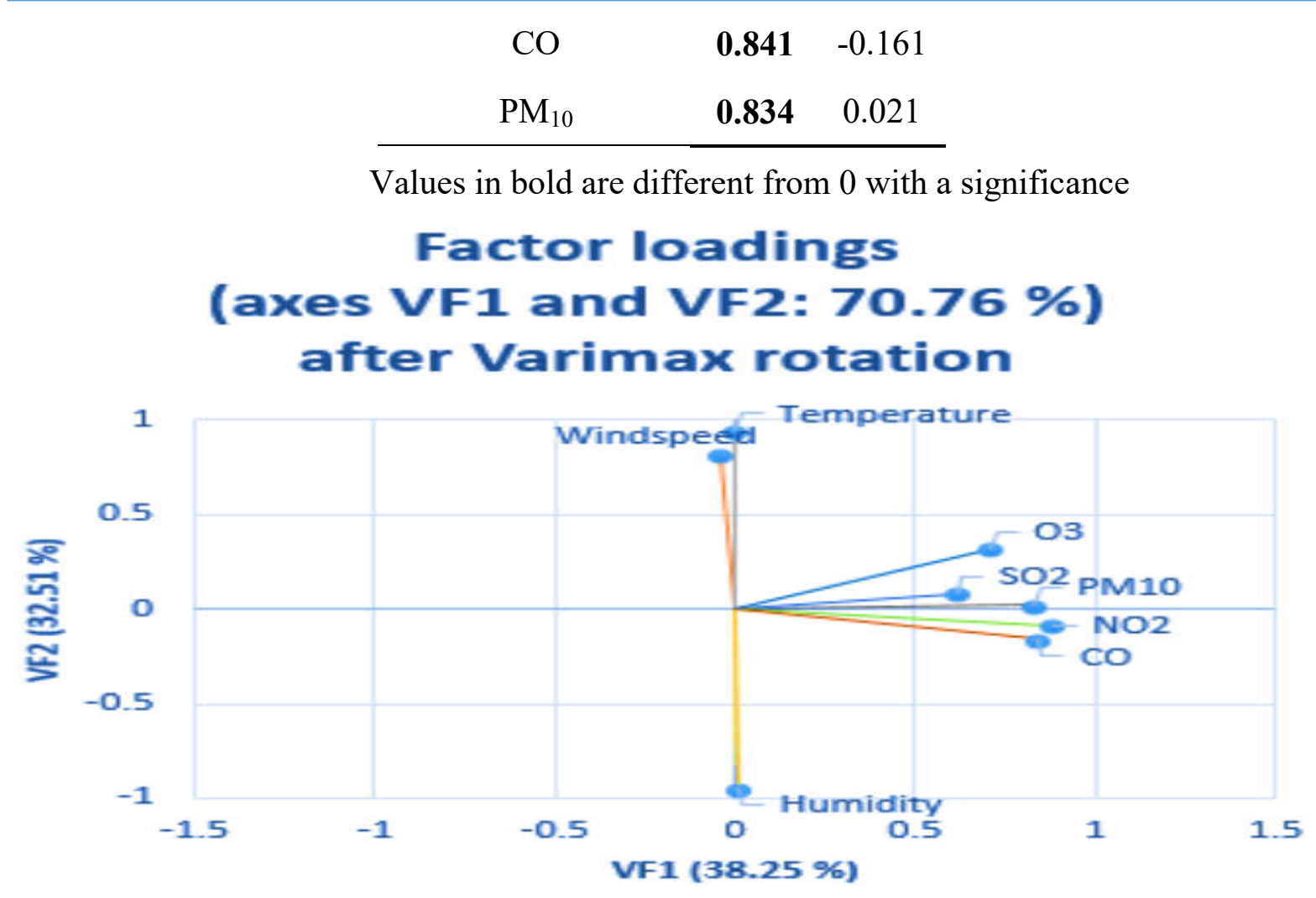

Fig.3. Factor loadings plot after level alpha $=0.05$ varimax rotation

The PCA gave out the strong factor loading result for $\mathrm{CO}$ with 0.841 . Based on previous studies, CO was the major environmental air pollutants sources in the Klang Valley that consist Shah Alam. It was primarily generated from the fuel's incomplete combustion of motor vehicles [16]. Reported by [19], USEPA indicated that $77 \%$ of the world CO productions originated from the transportation area. A huge percentage of $\mathrm{CO}$ production was recognized came from petroleum combustion in automobiles and power generation. Besides, incomplete petroleum combustion can also emit by industrial factories and motor vehicles, particularly when the motors are not turned completely which result to deficient burning [14]. In highly active area, the emission from idling vehicles could form hot spots in that particular area and worsen if high buildings exist around it [20]. This is supported by[16, 21] that the motor vehicles emissions are the major source of $\mathrm{CO}$ and $\mathrm{NO}_{2}$. Strengthened by the statistic made by [22], it was reported that the total amount of new registered motor vehicles in Malaysia increased by $4.42 \%$ from 934,367 in 2004 to 1,160,082 in 2010. Based on this information, it projected motor vehicles in Malaysia is one of the major factors that contribute to the decline of atmospheric conditions. 
The following strong factor loading in this study is $\mathrm{NO}_{2}$, with 0.875 , which is the strongest factor loading among three pollutants in the first varifactor. In previous studies, it suggested $\mathrm{NO}_{2}$ is one of major sources of outdoor air pollution in Shah Alam [19]. It is largely due to industrial activities as well as emission from traffic congestions [14]. Therefore, the main source of $\mathrm{NO}_{2}$ was from motor vehicle emission in high traffic areas [17]. This statement was also supported by study undertaken by [16] who approved that $\mathrm{NO}_{2}$ is a product of heavy traffic and industrial activity. Furthermore, according to [23], the emission from motor vehicles has increased as much as $14.3 \%$ from 2010 to 2014 .

A study also reported that amounts of $\mathrm{NO}_{2}$ is emitted by motor vehicles due to traces of nitrogen impurities in fuel could oxidizes into $\mathrm{NO}_{2}$, and its amount increases with the load and speed of the vehicles. As a result, it proposed that the heavy traffic in this area was a possible contributory factor to the increased in air pollutants level [19].

In addition to the above, $\mathrm{PM}_{10}$ was one of the major air pollutants in the Shah Alam after $\mathrm{CO}$ and $\mathrm{NO}_{2} . \mathrm{PM}_{10}$ which came from power generation, industrial activities, construction sites and vehicles emission were the examples of point source. Whereas, soil dust, open burning activity around the study area and also Sumatra bush burning were the examples of non-point source in Shah Alam [21, 24]. $\mathrm{PM}_{10}$ also produced by photochemical oxidation of its precursors as secondary pollutants under favourable atmospheric condition $[14,19]$. It was the main component of dust fall that transported from source point to non-source point.

In second VF, it shows strong factor loading towards temperature, humidity and wind speed. These meteorological conditions can affect the API level in this study area. As reported by [19], who stated that $\mathrm{PM}_{10}$ concentration is directly proportional to temperature reading but inversely proportional to humidity percentage. The existence of water [33-34] vapour can suspend the particulate matter away from ambient atmosphere, resulting low level of $\mathrm{PM}_{10}$ and lowering the dispersion of air pollutants in atmosphere [19]. As well, reported by [25], it was extremely crucial to consider the meteorological states on air pollution since they specifically control the dispersion of air pollutants in atmosphere.

\subsection{Determination of the Pattern and Trend of Each Pollutant in the Study Area}

From Fig. 4, $\mathrm{NO}_{2}$ have the mean of 0.031 with dispersion between 0.029 and 0.033 . Its standard control limit was 0.031 ppm, (Lower Control Limit) LCL and (Upper Control Limit) UCL was 
0.025 and 0.037 respectively. Referring to the RMAAQG for $\mathrm{NO}_{2}$, the permissible level is 0.17 ppm. From the obtained graph, the reading throughout five years had not exceeded the 0.17 though several readings were higher compared to other days. For instance, the reading on five spikes shown in the figure provided were $0.14,0.12,0.13,0.11$ and $0.14 \mathrm{ppm}$ happened in February 2009, and February, March and May 2010.

Referring to the pattern in Fig. 5, the control limit reading of CO was 1.156 ppm with most of the records was between 1.086 and $1.226 \mathrm{ppm}$ with the UCL was $1.366 \mathrm{ppm}$ and LCL was $0.945 \mathrm{ppm}$. Based on the graph and records, the highest reading was on $24^{\text {th }}$ June 2013 with $6.05 \mathrm{ppm}$, followed by $3.85 \mathrm{ppm}, 3.38 \mathrm{ppm}, 3.28 \mathrm{ppm}$ and $3.15 \mathrm{ppm}$ in different recorded dates throughout the years. Nonetheless, the reading of CO in Shah Alam was still following the RMAAQG which did not exceed 30ppm even though it had sudden spiked in June 2013. In June 2013, there was the southwest monsoon season. Malaysia was experiencing Southwest Monsoon season with hot and dry weather began in June 2013 and it continued until the beginning of October 2013.

During this season, the winds was blowing from Central Sumatra, Indonesia and dispersing the haze to the north-west coast of Peninsular Malaysia. On that current time, there are 227 hot spot detected in Indonesia [26]. Therefore, it rationalizes the high reading of $\mathrm{CO}$ and $\mathrm{PM}_{10}$ parameters which worsen the API reading on those days. Moreover, this phenomenon was the worst haze record affecting Malaysia and neighbouring countries such as Brunei and Singapore [27]. According to the report by DOE Malaysia on 2013, public were prohibited from practicing open burning in Selangor starting from $19^{\text {th }}$ June. In addition to that, ASMC also testified that 173 hot spot had been detected by satellite image NOAA [26].

Referring to Fig. 6, the mean reading was $70.963 \mu \mathrm{g} / \mathrm{m}^{3}$ with variation within $67.05 \mu \mathrm{g} / \mathrm{m}^{3}$ and $74.876 \mu \mathrm{g} / \mathrm{m}^{3}$. PM 10 's UCL, Cl and LCL were 82.701, 70.963 and 59.224 respectively. Most of the time $\mathrm{PM}_{10}$ level exceeded the RMAAQG, which was $150 \mu \mathrm{g} / \mathrm{m}^{3}$. The highest reading was on $24^{\text {th }}$ June 2013 with the value $507 \mu \mathrm{g} / \mathrm{m}^{3}$. The readings were always high during mid of the year with the reading $200 \mu \mathrm{g} / \mathrm{m}^{3}$ above. For example, the reading was $214 \mu \mathrm{g} / \mathrm{m}^{3}$ on $13^{\text {th }} \mathrm{July} 2009$ and the reading was $221 \mu \mathrm{g} / \mathrm{m}^{3}$ on $24^{\text {th }}$ June 2010 . For the following mid-year, the reading on $11^{\text {th }}$ July 2011 was $202 \mu \mathrm{g} / \mathrm{m}^{3}$. Next, the reading on $16^{\text {th }}$ June 2012 up to $272 \mu \mathrm{g} / \mathrm{m}^{3}$. Finally, the highest reading reached $507 \mu \mathrm{g} / \mathrm{m}^{3}$ on $24^{\text {th }}$ June 2013 . 
For overall reading, the mean level for API was accepted with control limit 59.25 and lower and upper control limit, 55.96 and 62.539 respectively. The trend and pattern of API for five years data was clearly shown in Fig. 7 that Shah Alam city had repeatedly faced an unhealthy API, in which the readings were above 100 . This happened mostly during the middle of the year for every year. For example during 2009, the highest reading was 145 on June 2009. However in following year 2010, the highest reading was recorded in beginning and mid of the year with 148 on January 2010, and 127 on July 2010. Again, in early 2011 which is February, the reading had increased to 158 and gradually decreased and increased until June 2012 when the reading reached 130. In the following year, it spiked to 301 on June 2013.

Based on the results above and SPC graphs provided in following page, this study found that the trends and patterns of the $\mathrm{NO}_{2}, \mathrm{CO}$ and $\mathrm{PM}_{10}$ reading were almost the same throughout 5 years data. $\mathrm{NO}_{2}$ showed fluctuation during certain months of the years that usually early and mid of the year such as the months of January to March and Jun to July. As mentioned by [21], parameter that showed the same daily pattern as $\mathrm{CO}$ was $\mathrm{NO}_{2}$. Furthermore, the Shah Alam air monitoring station is surrounded by industrial areas and a busy highway with addition of nearby Subang Airport and TUDM, all of which have the capability to emit high amounts of CO and $\mathrm{NO}_{2}[22]$.

The formation of $\mathrm{NO}_{2}$ was influenced by sunlight through photochemical reactions. In addition to that, high temperature due to the tropical climatic characteristics of Malaysia provides favourable condition for nitrogen oxides (NOx) and other VOCs to react, and high in $\mathrm{CO}$ concentration slowly helps to oxidized nitrogen monoxide (NO) to nitrogen dioxide $\left(\mathrm{NO}_{2}\right)$ which indirectly accelerates $\mathrm{O}_{3}$ formation [14]. Therefore, it indicates the occurrence of dry season in Shah Alam due to monsoon, especially southwest monsoon has encouraged the formation and dispersion of $\mathrm{NO}_{2}$ which can be seen through the trend that the increasing and decreasing of the data recorded was in-line with the monsoons event [28].

Other than that, the trends and patterns of $\mathrm{CO}$ and $\mathrm{PM}_{10}$ commonly similar and usually increase during Jun and July. It was mentioned that Shah Alam was one of the city that is highly influenced by $\mathrm{PM}_{10}$ during the south-west monsoon [19], which wind was predominantly blow from south-westerly and lowered during north-east monsoon [29]. In addition to that, the dispersion of $\mathrm{CO}$ and $\mathrm{PM}_{10}$ are also influenced by the meteorological conditions [9]. 
As for API trend, it is influence by the overall reading of pollutants but the major influencer are $\mathrm{PM}_{10}[30]$. From the graphs provided, this study is aware that the readings of air pollutants and API were mostly within control limit for most all the time starting 2012. During 2009 until 2011, the readings were above the control limit which shows the awareness and proactive steps towards clean air was not yet taken. However, in 2012, Environmental Quality Act (amendment) 2012 had been issued and the enforcement of Environmental Quality (Clean Air) regulations 2014 was done by Federal Government Gazette [31].

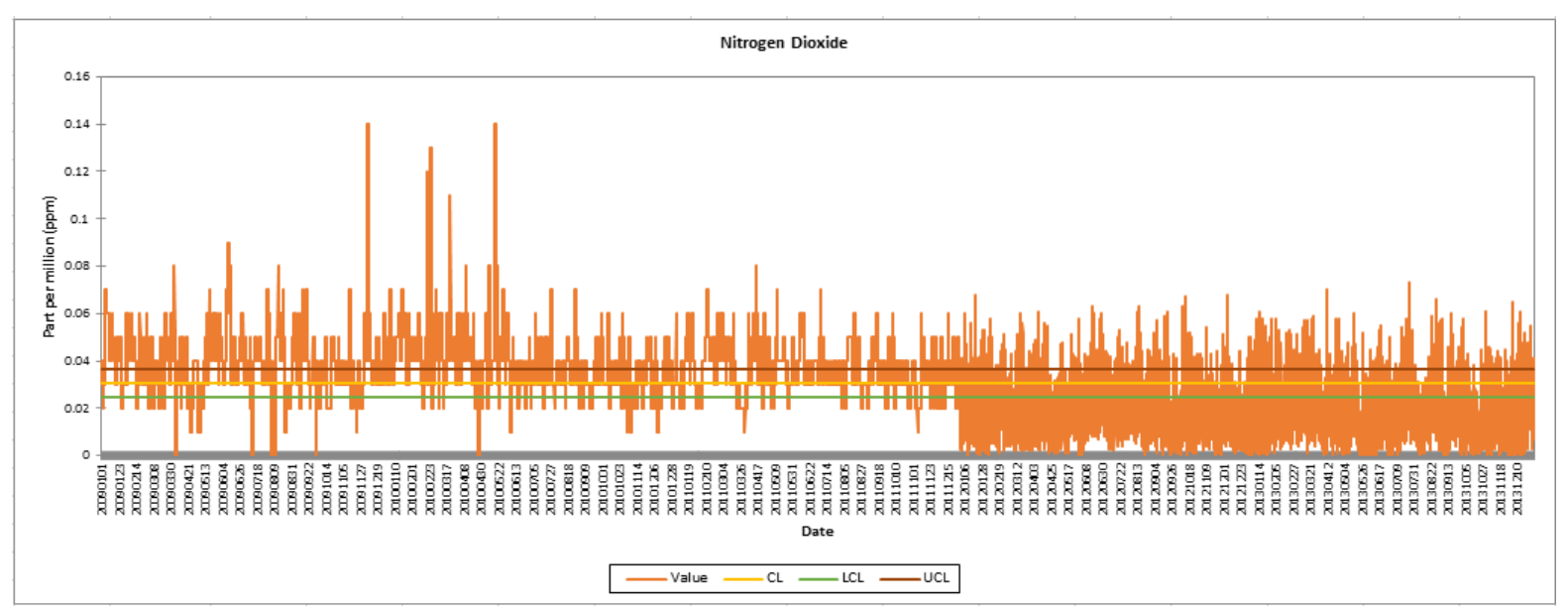

Fig.4. SPC graph for nitrogen dioxide for year 2009-2013

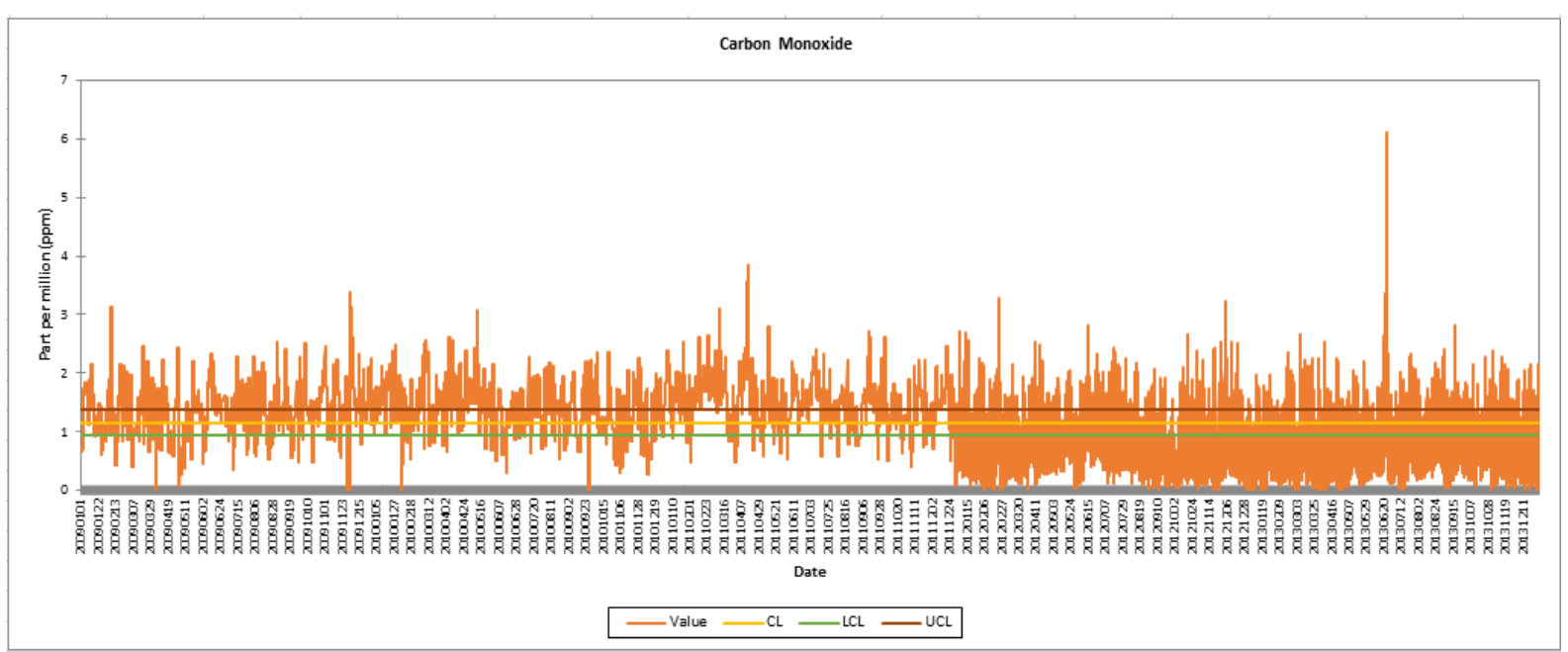

Fig.5. SPC graph for carbon monoxide for year 2009-2013 


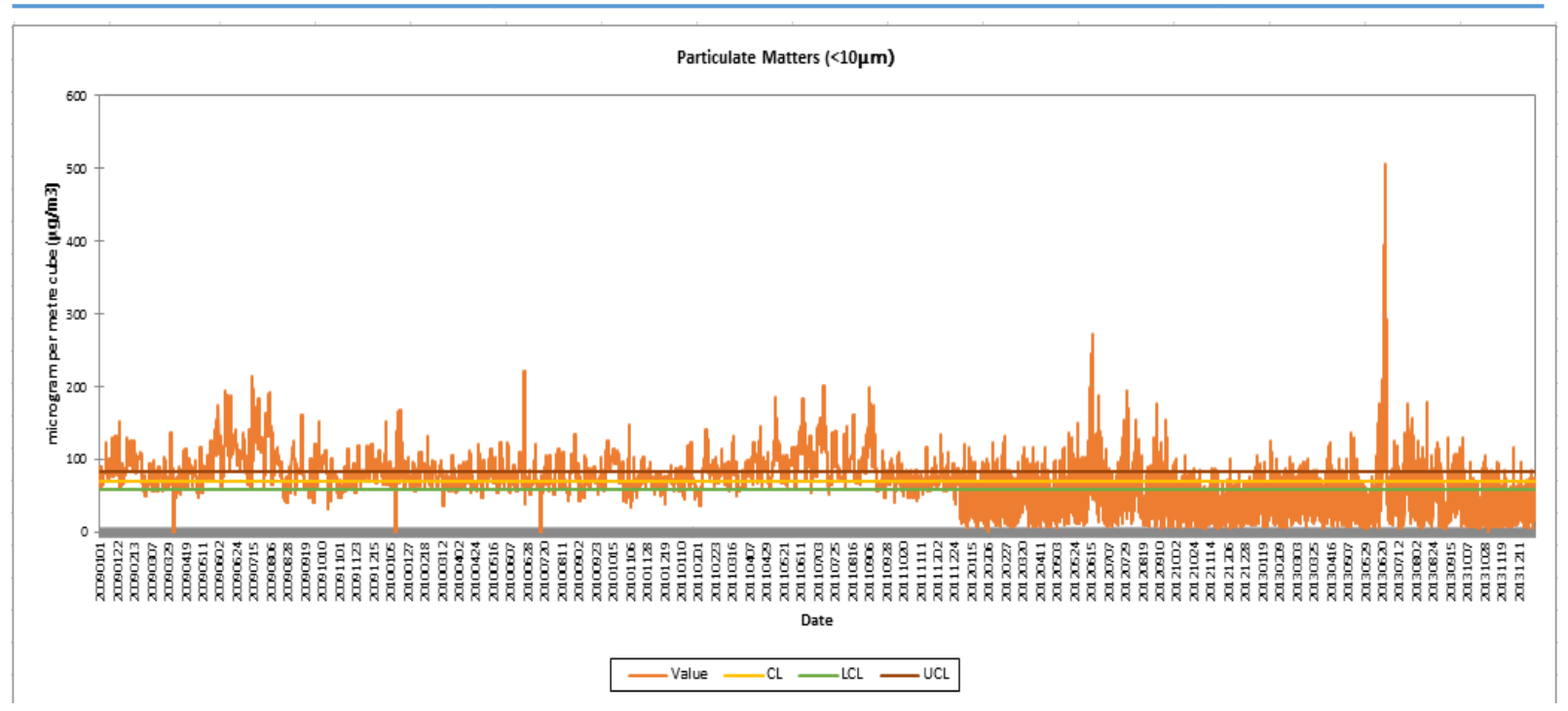

Fig.6. SPC graph for particulates matter $(<10)$ for year 2009-2013

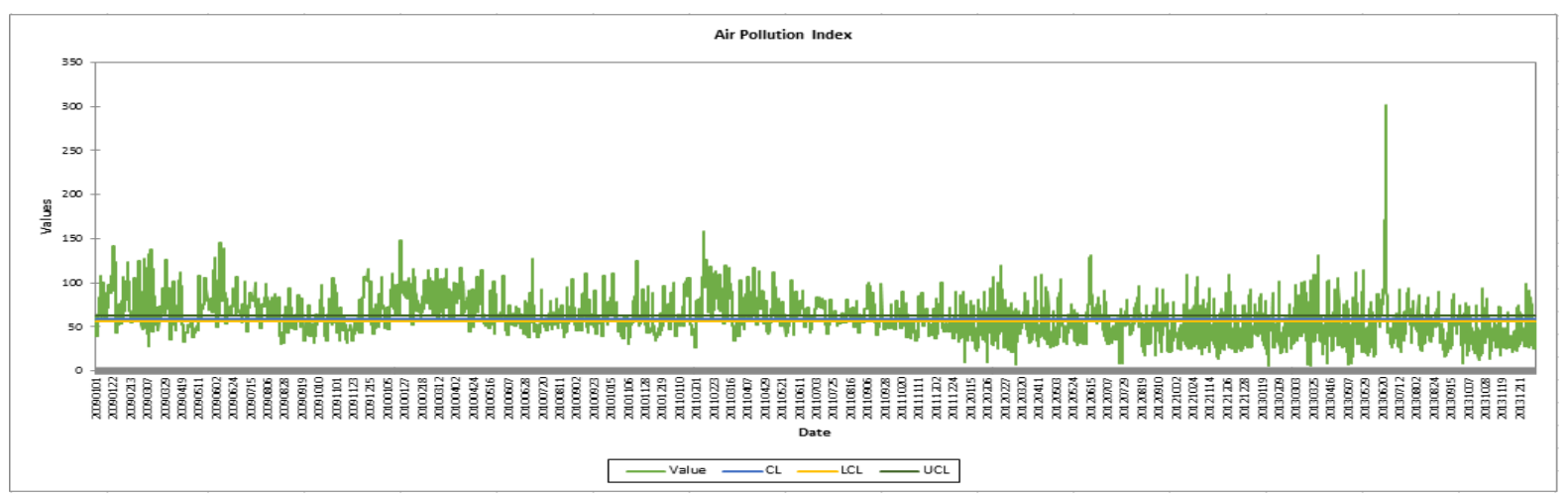

Fig.7. SPC graph for API for year 2009-2013

\subsection{Determination of the Relationship between Air Pollution with Meteorological Factors}

From Table 3, the correlations between $\mathrm{SO}_{2}, \mathrm{NO}_{2}, \mathrm{O}_{3}, \mathrm{CO}, \mathrm{PM}_{10}$, API with meteorological factors were low. The correlation between $\mathrm{SO} 2$ with $\mathrm{NO} 2, \mathrm{O} 3, \mathrm{CO}$ and PM10 are fair, and correlation between $\mathrm{NO} 2$ with $\mathrm{O}_{3}, \mathrm{CO}$ and PM10 is moderate; as well as the correlation between wind-speed with temperature and humidity. However, in this study, only correlation with value 0.7 above will be considered for further discussion as done by [19].

Based on result, high correlation related to meteorological factors is only between humidity and temperature with value -0.937 . This suggest that when the ambient temperature increases automatically humidity decrease. This is due to the evaporation process happen and consequently reducing the amount of moisture in surrounding atmosphere [32]. In addition, high correlation between pollutant and API level was only between $\mathrm{O}_{3}$ and API with value 
0.791. However, this value was not with significant level alpha (0.05). Therefore, it will not be discussed further in this study.

Table 3. The Spearman correlation matrix between variables

\begin{tabular}{cccccccccc}
\hline & Wind & & & & & & & & \\
Var. & Speed & Temp. & Humid & $\mathbf{S O}_{2}$ & $\mathbf{N O}_{2}$ & $\mathbf{O}_{\mathbf{3}}$ & $\mathbf{C o}$ & $\mathbf{P M 1 0}$ & API \\
\hline Wind & & & & & & & & & \\
speed & $\mathbf{1}$ & 0.633 & $\mathbf{- 0 . 6 4 4}$ & 0.015 & $\mathbf{- 0 . 0 8 9}$ & 0.240 & $\mathbf{- 0 . 1 5 3}$ & $\mathbf{- 0 . 0 2 6}$ & 0.055 \\
Temp. & 0.633 & $\mathbf{1}$ & $\mathbf{- 0 . 9 3 7}$ & 0.070 & $\mathbf{- 0 . 0 5 9}$ & 0.224 & $\mathbf{- 0 . 1 0 4}$ & 0.026 & 0.122 \\
Humid & $\mathbf{- 0 . 6 4 4}$ & $\mathbf{- 0 . 9 3 7}$ & $\mathbf{1}$ & $\mathbf{- 0 . 0 6 0}$ & 0.075 & $\mathbf{- 0 . 2 1 9}$ & 0.122 & $\mathbf{- 0 . 0 2 5}$ & $\mathbf{- 0 . 1 1 7}$ \\
$\mathrm{SO}_{2}$ & 0.015 & 0.070 & $\mathbf{- 0 . 0 6 0}$ & $\mathbf{1}$ & 0.414 & 0.365 & 0.398 & 0.383 & 0.364 \\
$\mathrm{NO}_{2}$ & $\mathbf{- 0 . 0 8 9}$ & $\mathbf{- 0 . 0 5 9}$ & 0.075 & 0.414 & $\mathbf{1}$ & 0.534 & 0.732 & 0.652 & 0.594 \\
$\mathrm{O}_{3}$ & 0.240 & 0.224 & $\mathbf{- 0 . 2 1 9}$ & 0.365 & 0.534 & $\mathbf{1}$ & 0.427 & 0.530 & 0.791 \\
$\mathrm{CO}$ & $\mathbf{- 0 . 1 5 3}$ & $\mathbf{- 0 . 1 0 4}$ & 0.122 & 0.398 & 0.732 & 0.427 & $\mathbf{1}$ & 0.632 & 0.526 \\
$\mathrm{PM}_{10}$ & $\mathbf{- 0 . 0 2 6}$ & 0.026 & $\mathbf{- 0 . 0 2 5}$ & 0.383 & 0.652 & 0.530 & 0.632 & $\mathbf{1}$ & 0.670 \\
$\mathrm{API}$ & 0.055 & 0.122 & $\mathbf{- 0 . 1 1 7}$ & 0.364 & 0.594 & 0.791 & 0.526 & 0.670 & $\mathbf{1}$ \\
\hline
\end{tabular}

Values in bold are different from 0 with a significance level alpha $=0.05$

The correlation between $\mathrm{NO}_{2}$ and $\mathrm{CO}$ is 0.732 . The association between these pollutants can be demonstrated by their sources that came from industrial and traffic activities. Motor vehicles emissions are the major source of $\mathrm{CO}$ and $\mathrm{NO}_{2}$ as indicated by several studies conducted by [10, 16]. As the air monitoring stations for this study are located in urban areas of dense-development in the Shah Alam, the reading was affected by heavy traffic, particularly during the morning and late afternoon rush hours [16]. The level of traffic during working hours was expected to be low and at the same time showing low the concentration of $\mathrm{NO}_{2}$ and $\mathrm{CO}$ in the atmosphere compared to after working hours. Both of these readings increase as the evening working hour ends and people start returning from work [9, 21].

This situation confirms the moderate but nearly high contribution of traffic movement towards the level of $\mathrm{NO}_{2}$ and $\mathrm{CO}$ parameter. Regardless the activities that are on-going in this city, government and local authorities have brought their proactive steps in controlling the air quality status. It is done by proper policies and enforcement towards public and industries to sustain the good air quality status of the city. 


\section{CONCLUSION}

The outcome demonstrates that climate condition, gas, non-gas and secondary air pollutants are manipulating the level of air quality in the Shah Alam, Selangor. The sources of pollutants are accounted for more than $38.302 \%$ and $32.457 \%$ of the total variance. It shows that higher numbers of motor vehicles, industries and other activities in Shah Alam city, it increases $\mathrm{NO}_{2}$, $\mathrm{O}_{3}$ and $\mathrm{PM}_{10}$ formation and also $\mathrm{CO}$ emission. Even though humidity, ambient temperature and wind speed had low correlation to the concentration of air pollutants in these areas at overall time, there are possibilities that the air pollution became worse at certain time of the years such as during hot and dry season compared to wet season. As discussed before, Shah Alam city recorded the inconsistent and unhealthy reading from 2009-2011 with all of the pollutants had some of reading above the RMAAQG. Starting 2012-2013, the air quality reading had showed improvement due to enforcement of new regulation under Environmental Quality Act (amendment) 2012. It was one of proactive steps that government had taken seriously, and the result can be seen with the improvement of the air quality in the study area.

\section{REFERENCES}

[1] Abdullah S, Ismail M, Fong S Y, Ahmed A M A N. Evaluation for long term PM10 concentration forecasting using multi linear regression. Environment Asia, 2016, 9(2):101-110 [2] Valavanidis A, Vlachogianni T, Fiotakis K. Air pollution as a significant cause of diseases and premature death. 2016, https://www.chem-tox-ecotox.org

[3] Department of Environment (DOE) Malaysia. Air quality. Putrajaya: Ministry of Natural Resources and Environment, 2013

[4] Latif M T, Dominick D, Ahamad F, Khan M F, Juneng L, Hamzah F M, Nadzir M S M. Long term assessment of air quality from a background station on the Malaysian Peninsula. Science of the Total Environment, 2014, 482(1):336-348

[5] Shah Alam City Council (MBSA) Malaysia. Modern city of industry. Selangor: MBSA, 2016

[6] Balakeristanan M L, Md Said A M. Land use land cover change detection using remote sensing application for land sustainability. AIP Conference Proceedings, 2012, 
1482(1):425-430

[7] Rostam K, Mat Jali M F, Toriman M E. Impacts of globalisation on economic change and metropolitan growth in Malaysia: Some regional implications. The Social Sciences, 2010, 5(4):293-301

[8] Masron T, Yaakob U, Mohd Ayob N, Mokhtar A S. Population and spatial distribution of urbanisation in Peninsular. Malaysia Journal of Society and Space, 2012, 2(2):20-29

[9] Azmi S Z, Latif M T, Ismail A S, Juneng L, Jemain A A. Trend and status of air quality at three different monitoring stations in the Klang Valley, Malaysia. Air Quality, Atmosphere and Health, 2010, 3(1):53-64

[10] Isiyaka H A, Juahir H, Toriman M E, Gasim B M, Azid A, Amri M K, Ibrahim A, Usman U N. Spatial assessment of air pollution index using environ metric modeling techniques. Advances in Environmental Biology, 2014, 8(24):244-256

[11] Park H M. Univariate analysis and normality test using SAS, STATA, and SPSS. Indiana: The Trustees of Indiana University, 2006

[12] Azid A, Juahir H, Amran M A, Suhaili Z, Osman M R, Muhamad A, Abidin I Z, Sulaiman N H, Saudi A S M. Spatial air quality modelling using chemometrics techniques: A case study in Peninsular Malaysia. Malaysian Journal of Analytical Sciences, 2015, 19(6):1415-1430

[13] Corbett C J, Pan, J N. Evaluating environmental performance using statistical process control techniques. European Journal of Operational Research, 2002, 139(1):68-83

[14] Isiyaka H A, Juahir H, Toriman M E, Azid A, Gasim M B, Kamarudin M K A. Assessment of the spatial variation and source apportionment of air pollution based on chemometric techniques: A case study in the peninsular Malaysia. Jurnal Teknologi, 2015, $77(1): 33-34$

[15] Azid A, Juahir H, Toriman M E, Kamarudin M K A, Saudi A S M, Hasnam C N C, Aziz N A A, Azaman F, Latif M T, Zainuddin S F M, Osman M R, Yamin M. Prediction of the level of air pollution using principal component analysis and artificial neural network techniques: A case study in Malaysia. Water, Air, and Soil Pollution, 2014, 225(8):1-14

[16] Dominick D, Juahir H, Latif M T, Zain S M, Aris A Z. Spatial assessment of air quality patterns in Malaysia using multivariate analysis. Atmospheric Environment, 2012, 
60:172-181

[17] Isiyaka H A, Toriman E M, Juahir H. Application of principal component analysis and multiple linear regression for air pollution modeling in selected monitoring stations in Malaysia. Elixir Pollution, 2015, 83:32957-32962

[18] Mutalib S N S A, Juahir H, Azid A, Sharif S M, Latif m T, Aris A Z, Zain S M, Dominick D. Spatial and temporal air quality pattern recognition using environmetric techniques: A case study in Malaysia. Environmental Science: Processes and Impacts, 2013, 15(9):1717-1728

[19] Rahman S R A, Ismail S N S, Ramli M F, Latif M T, Abidin E Z, Praveena S M. The assessment of ambient air pollution trend in Klang Valley, Malaysia. World Environment, 2015, 5(1):1-11

[20] Vallero D, Vallero D. Chapter 14-Air pollution's impact on ecosystems. In A. A. Stern (Ed.), Fundamentals of air pollution. New York: Academic Press, 2014, pp. 341-368

[21] Isiyaka H A, Juahir H, Toriman M E, Gasim B M, Azid A, Amri M K, Ibrahim A, Usman U N. Spatial Assessment of air pollution index using environ metric modeling techniques. Advances in Environmental Biology, 2014, 8(24):244-256

[22] Ministry Of Transport (MOT) Malaysia. Transport statistic Malaysia 2015. Putrajaya: MOT, 2015

[23] Department of Statistics Malaysia (DOSM). Press release-Compendium of environment statistics 2015. Putrajaya: DOSM, 2015

[24] Vallero D, Vallero D. Chapter 29-Air pollutant emissions. In A. A. Stern (Ed.), Fundamentals of air pollution. New York: Academic Press, 2014, pp. 787-827

[25] Isiyaka H A, Azid A. Air quality pattern assessment in Malaysia using multivariate techniques. Malaysian Journal of Analytical Sciences, 2015, 19(5):966-978

[26] Department of Environment (DOE) Malaysia. Kenyataan akhbar oleh Jabatan Alam Sekitar pada 26 Jun 2013 (Rabu). Putrajaya: Ministry of Natural Resources and Environment, 2013

[27] Rahman H A. Haze phenomenon in Malaysia: Domestic or transboudry factor? In 3rd International Journal Conference on Chemical Engineering and its Applications, 2013, pp. 597-599

[28] Malaysian Meteorological Department (MET). Perubahan hujan bermusim di 
Semenanjung Malaysia. Selangor: MET, 2017

[29] Sahani M, Khan M F, Mahiyuddin W R W, Latif M T, Ng C F S, Yussoff M F, Abdullah A A, Choy E A, Tahir N M. Air pollution and health in Malaysia. In D. C. Shin (Ed.), Hazardous air pollutants: Case studies from Asia. Florida: CRC Press, 2016, pp. 97-114

[30] Department of Environment (DOE) Malaysia. A guide to air pollutant index (API) in Malaysia. Putrajaya: Ministry of Natural Resources and Environment, 2000

[31] Department of Environment (DOE) Malaysia. Environmental quality (clean air) regulations 2014. Putrajaya: Ministry of Natural Resources and Environment, 2014

[32] Weli V, Adegoke J O. The influence of meteorological parameters and land use on the seasonal concentration of carbon monoxide (CO) in the industrial coastal city of Port Harcourt, Nigeria. Journal of Pollution Effects and Control, 2016, 4(4):1-8

[33] Kamarudin M K, Nalado A M, Kasmuri A, Toriman M E, Juahir H, Umar R, Jamil N R, Saudi A S, Rizman Z I, Gasim M B, Hassan A R. Assessment of river plan changes in Terengganu River using RS and GIS method. Journal of Fundamental and Applied Sciences, $2017,9(2 \mathrm{~S}): 28-45$

[34] Saudi A S, Kamarudin M K, Ridzuan I S, Ishak R, Azid A, Rizman Z I. Flood risk index pattern assessment: Case study in Langat river basin. Journal of Fundamental and Applied Sciences, 2017, 9(2S):12-27

\section{How to cite this article:}

Zakaria U.A., Saudi A.S.M., Abu I.F., Azid A, Balakrishnan A, Amin NA, Rizman ZI. The assessment of ambient air pollution pattern in shah alam, selangor, Malaysia. J. Fundam. Appl. Sci., 2017, 9(4S), 772-788. 